DOI: $10.21802 / \mathrm{acm} .2021 .2 .7$

UDC 616-099+547.262+616.681

\title{
INFLUENCE OF CHRONIC ETHANOL INTOXICATION ON HEMODYNAMICS IN TESTICLES AND SPERMATOGENESIS IN MIDDLE-AGED MALES ${ }^{1}$ Hotiur OI, ${ }^{2}$ Hrytsuliak BV, ${ }^{1}$ Vakaliuk IP, Lytvynets YA, ${ }^{1}$ Tymochko NB

\author{
1 - Ivano-Frankivsk National Medical University, Ivano-Frankivsk;
} \\ 2 - Vasyl Stefanyk Precarpathian National University, Ivano-Frankivsk
}

\begin{abstract}
Diseases of testicles are an important social problem because according to WHO data, the male factor is about $45 \%$ in the structure of sterile marriage. Among many pathogenic factors distorting spermatogenic and endocrine function of testicles, acute and chronic circulatory disorders in them play a great role. Recent studies showed that one of the causes of male infertility is chronic ethanol intoxication causing distorted hemomicrocirculation in testicles, so determining the character of cytologic changes in them in these circumstances remains relevant.

Objects and methods. In the study, we used 14 histological micropreparations from testicular biopsy specimens from middle-aged infertile males (22-35 years) with chronic alcoholism in anamnesis,. In some biopsy specimens, ultrastructural changes in testicles were studied under the electronic microscope, testicular hemodynamics in infertile males was examined with ultrasound.

Results. In middle-aged infertile males with chronic alcoholism, the volume of testicles decreases compared to normal. The arterial blood flow rate in them decreases significantly. The diameter of tortuous looped seminiferous tubules decreases compared to normal. Their membrane is thickened; the layers of spermatogenic epithelial cells are reduced. The volume of interstitial endocrinocytes decreases compared to normal. Testosterone level in blood decreases too.

Ultrastructural changes in testicles are manifested with irregular thickness and curving of spermatogenic epithelial basal membrane, vacuolization of myoid cellular, supporting epitheliocytes, and interstitial endocrinocyte cytoplasm with reduced mitochondrial cristae and tubules in the endoplasmic reticulum. In ejaculate of infertile males, sperm concentration decreases to $(30.65 \pm 1.70) \mathrm{million} / \mathrm{ml}$ compared to $(75.80 \pm 4.20) \mathrm{million} / \mathrm{ml}$, the number of pathologic forms of spermatozoids increases twice, the number of spermatozoids with progressive movement decreases.
\end{abstract}

Keywords: chronic alcoholism, testis, spermatozoon.

Introduction. Diseases of testicles are an important social problem because according to WHO data, the male factor is about $45 \%$ in the structure of sterile marriage $[1,3,4]$. Among many pathogenic factors distorting spermatogenic and endocrine function of testicles, acute and chronic circulatory disorders in them play a great role $[5,6,8]$. Recent studies showed that one of the causes of male infertility is chronic ethanol intoxication causing distorted hemomicrocirculation in testicles, so determining the character of cytologic changes in them in these circumstances remains relevant.

According to the literature, Ukraine has one of the first places in Europe for the standardized mortality coefficient from effects of alcohol consumption in recent years [9], and in 2018 our state became a world leader by underage alcoholism level. An increase in the significant number of different alcoholic products caused an increase in the liver, cardiovascular, and particularly reproductive diseases. Pathology of the last ones in males causes infertility.

Aim. To determine the influence of ethanol intoxication on hemodynamics in testicles and spermatogenesis in middle-aged males.

\section{Study objects and methods}

Inthestudy, we used 14histologicalmicropreparations from testicular biopsy specimens from middle-aged

infertile males (22-35 years) with chronic alcoholism in anamnesis, that were collected for diagnostic purposes in the Department of Urology of CNE "Ivano-Frankivsk Regional Clinical Hospital". In some biopsy specimens, ultrastructural changes in testicles were studied under the PEM-125K electronic microscope at $6000 \mathrm{x}$ to $10000 \mathrm{x}$ magnification. Testicular hemodynamics in infertile males was examined on the SIEMENS SONOLINE G60S ultrasound system (Siemens AG, Germany) in a clinical diagnostic center.

In each testicular biopsy specimen, we detected the diameter of tortuous looped seminiferous tubules, amount of germ cells, and the volume of interstitial endocrinocytes nuclei. In these males' ejaculate, we determined sperm concentration, its morphological forms, percentage of living forms, and motility according to the methods proposed by I. S. Chornokulskyi (2013). Testosterone level in blood was determined with enzyme immunoassay with the help of IMMULITE 2000 immunoassay system (Siemens Healthcare Diagnostics Inc., USA).

Statistical analysis was done with the Statistica 6 software.

\section{Results of the study and discussion}

According to the data of the Doppler of testicular vascular anatomy in infertile males, the average maximal blood flow rate in a testicular artery within the 
spermatic cord is $(16.3 \pm 1.2) \mathrm{cm} / \mathrm{sec}$ compared to normal $(19.0 \pm 1.5) \mathrm{cm} / \mathrm{sec}$. Within parenchyma of testis under tunica albuginea, the value is significantly lower and is $(9.7 \pm 1.5) \mathrm{cm} / \mathrm{sec}$ compared to normal $(12.4 \pm 1.2) \mathrm{cm} /$ sec. The average minimal blood flow rate in a testicular artery within the spermatic cord decreases to $(6.3 \pm 1.5)$ $\mathrm{cm} / \mathrm{sec}$ compared to normal $(7.6 \pm 1.2) \mathrm{cm} / \mathrm{sec}$, and in a testicular artery within parenchyma to $(4.2 \pm 0.9) \mathrm{cm} / \mathrm{sec}$ compared to $(6.3 \pm 1.0) \mathrm{cm} / \mathrm{sec}$ accordingly. The volume of the testis decreases in these conditions to (17.0 \pm 1.4$)$ cm3 compared to normal $(19.3 \pm 1.2) \mathrm{cm} 3$ on average.

In ejaculate of middle-aged infertile males with this pathology, sperm concentration decreases to $(30.65 \pm 1.70)$ million $/ \mathrm{ml}$ compared to normal (75.80 \pm 4.20$)$ million $/ \mathrm{ml}$. In these circumstances, the number of pathological forms of spermatozoids including spermatozoids with the pathology of the head (absent acrosome, doubled headed) increases to 35\% compared to $15.8 \%$. The number of spermatozoids with progressive motility decreases significantly $(32 \%$ compared to normal $76 \%$ ). Forrisa fertility indicator decreases to 78.3 IU compared to $220 \mathrm{IU}$.

During the cytologic examination of micropreparations from testicular biopsy specimen in infertile males, the diameter of tortuous looped seminiferous tubules decreases to $(160.3 \pm 5.0) \mu \mathrm{m}$ compared to normal $(218,7 \pm 1,5) \mu \mathrm{m}$. Seminiferous tubules are of irregular form; their layer is thicker to 45$50 \mu \mathrm{m}$ with signs of arteriolosclerosis and sclerosis (Fig. 1).1-2 layers of germinal cells are connected to it namely spermatogonia and spermatocytes. In the part of tubules, there is intraluminal cellular detritus. The number of spermatogonia decreases to $39.0 \pm 1.2$, spermatocytes to $58.0 \pm 4.1$, and spermatids to $139.0 \pm 6.9$. The volume of interstitial endocrinocyte nuclei decreases to $(60.5 \pm 3.6)$

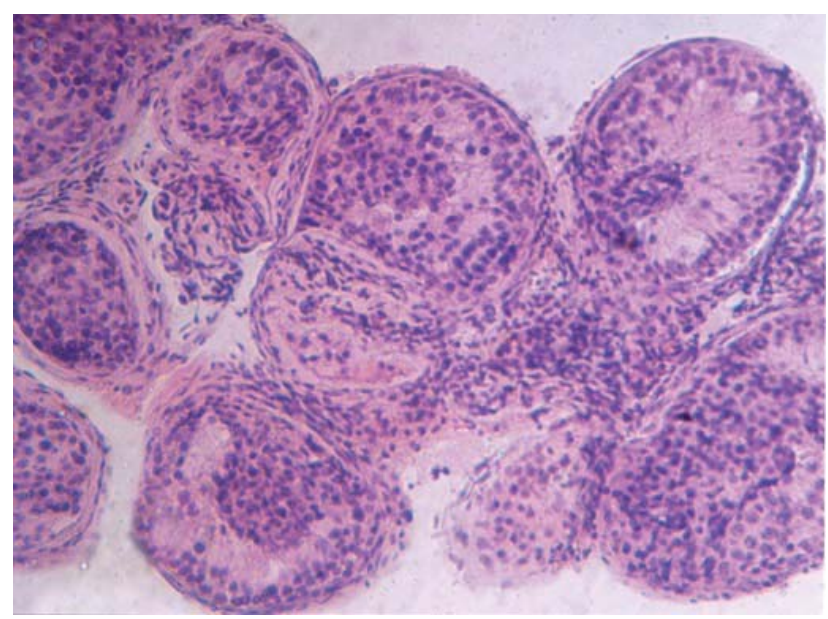

Figure 1. Significantly deformed tortuous looped seminiferous tubules in a 30 -year-old male with chronic alcoholism. 1-2 layers of germinal epithelial cells are connected to the own layers of the tubules. Photomicrography. Stained with hematoxylin and eosin $\mu \mathrm{m} 3$ compared to normal $(97.5 \pm 1.5) \mu \mathrm{m} 3$. Testosterone level in blood decreases to $(375.0 \pm 25.0) \mathrm{ng} / \mathrm{dl}$ compared to normal $(688.0 \pm 21.0) \mathrm{ng} / \mathrm{dl}$.

According to the data electronic microscopy of the testicular biopsy specimen, the basal membrane of spermatogenic epithelium is irregularly thickened and curved in the layer of tortuous looped seminiferous tubules. In the cytoplasm of peritubular myoid cells, myofilaments are not detected, it is vacuolized, mitochondrial cristae are reduced (Fig. 2).

Interstitial endocrinocyte nuclei are deformed, chromatinis condensednearnucleolemma, mitochondrial cristae are reduced. Interstitial endocrinocyte nuclei are deformed with peripheral chromatin concentration, the cytoplasm is reduced, mitochondrial cristae are not detected. The same changes are present in the cytoplasm of supporting epitheliocytes and spermatocytes (Fig.3).

\section{Conclusions}

1. In middle-aged infertile males with chronic alcoholism, the volume of testicles decreases to $(17.0 \pm 1.4) \mathrm{cm} 3$ compared to normal $(19.3 \pm 1.2) \mathrm{cm} 3$. The arterial blood flow rate in them decreases significantly. The diameter of tortuous looped seminiferous tubules decreases to $(160.3 \pm 5.0) \mu \mathrm{m}$ compared to normal (218.7 \pm 1.55$) \mu \mathrm{m}$. Their membrane is thickened; the layers of spermatogenic epithelial cells are reduced. The volume of interstitial endocrinocytes decreases to (60.5 \pm 3.6$) \mu \mathrm{m} 3$ compared to normal $(97.5 \pm 1.5) \mu \mathrm{m} 3$. Testosterone level in blood decreases to $(375.0 \pm 25.0)$ $\mathrm{ng} / \mathrm{dl}$ compared to normal $(688.0 \pm 21.0) \mathrm{ng} / \mathrm{dl}$.

2. Ultrastructural changes in testicles are manifested with irregular thickness and curving of spermatogenic epithelial basal membrane, vacuolization of myoid cellular, supporting epitheliocytes, and interstitial

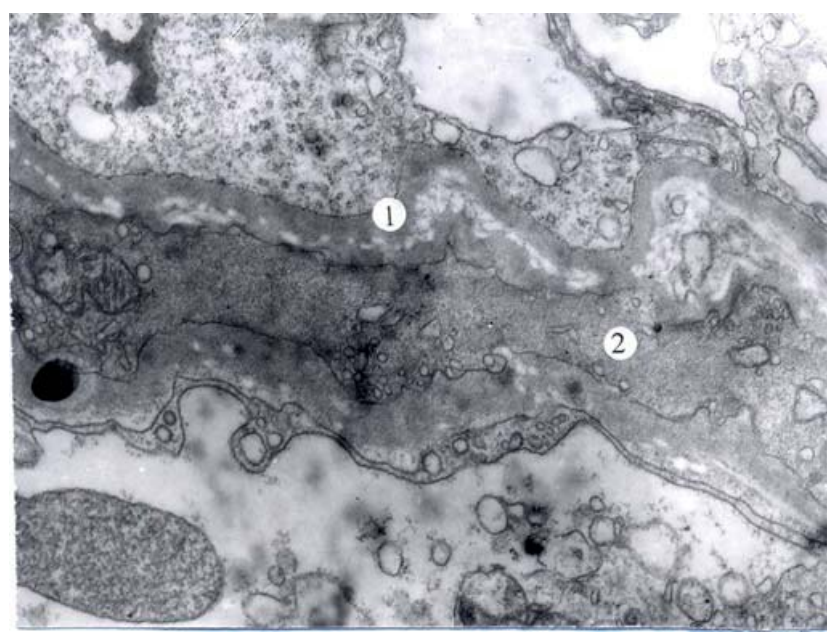

Figure 2. The curved basal membrane of the endothelium (1) and deformed sprout cytoplasm of peritubular myoid cells (2) in a 32-year-old male with chronic alcoholism. Electronic photomicrography. MAG $\times 20000$ 


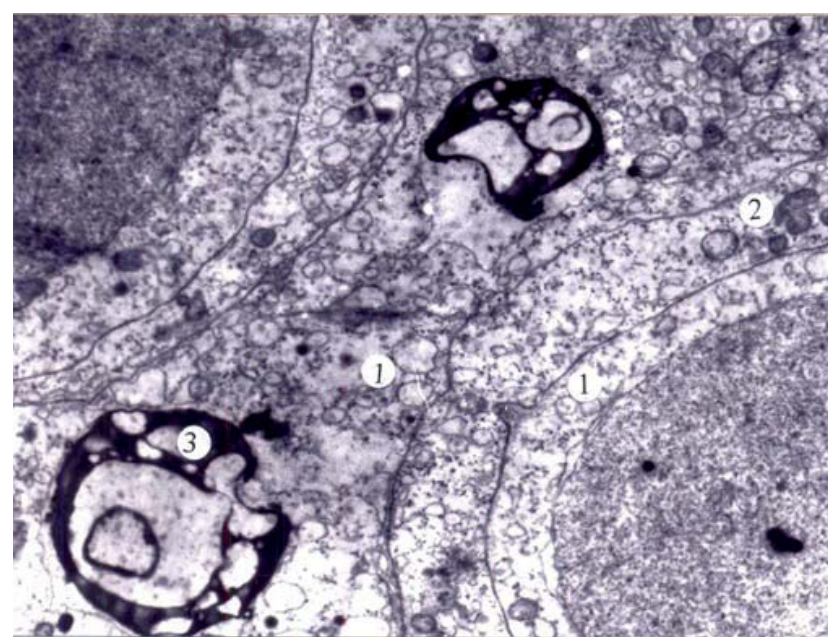

Figure 3. Cytoplasmic vacuolization of a supporting epitheliocyte (1) spermatocytes, reduced mitochondrial cristae in them (2), accumulation of lysosomes (3) in a testicle in a 32-year-old male with chronic alcoholism. Electronic photomicrography. MAG $\times 10000$

endocrinocyte cytoplasm with reduced mitochondrial cristae and tubules in the endoplasmic reticulum.

3. In ejaculate of infertile males, sperm concentration decreases to $(30.65 \pm 1.70)$ million $/ \mathrm{ml}$ compared to (75.80 \pm 4.20$)$ million $/ \mathrm{ml}$, the number of pathologic forms of spermatozoids increases twice, the number of spermatozoids with progressive movement decreases.

Ethics policy. All researches involving participants were conducted in accordance with the World Medical Association Declaration of Helsinki. All patients have signed an informed consent before involvement into the study.

Financial Disclosure. Authors declared no financial support.

Conflict of Interests. The author declared that no conflict of interests existed.

\section{References}

1. Hotiur OI, Kocherzhat OI, Vasylechko MM, Vakaliuk
II. Vliyanie sostoyaniya gisto- i ultrastruktur yaichka na reproduktivnuyu funktsiyu muzhchin 22-35 let pri varikotsele. Georgian medical news. 2020:6(303);45-8. [in Russian].

2. Hotiur OI. Strukturno-funktsionalni osoblyvosti yayechka ta nadyayechka u cholovikiv reproduktyvnoho viku (22-35 rokiv) v normi. GMJ. 2012;19(2):24-6. [in Ukrainian].

3. Hrytsuliak BV, Hrytsuliak VB, Dolynko NP, Lytvynets YA, Ivasiv VA. Kharakter tsytolohichnykh zmin $\mathrm{v}$ yayechkakh neplidnykh cholovikiv zriloho viku, zumovlenykh alkoholizmom. Bulletin of Problems Biology and Medicine. 2019;4.1(153):221-3. [in Ukrainian].

4. Hrytsuliak BV, Hrytsuliak VB, Hlodan NP, Dolynko NP, Spaska AM. Kharakter tsytolohichnykh zmin v klitynakh spermatohennoho epiteliyu I eyakuliatu $\mathrm{v}$ umovakh etanolovoyi intoksykatsiyi. World of Medicine and Biology. 2018;3(65):143-6. [in Ukrainian].

5. Bazalytska SV. Osoblyvosti ekspresiyi hematotestykulyarnoho baryeru pry riznykh formakh cholovichoyi neplidnosti. World of Medicine and Biology. 2015;2(49):80-3. [in Ukrainian].

6. Hrytsuliak BV, Hrytsuliak VB, Dolynko NP, Lytvynets YA, Ivasiv VA. Kharakter tsytolohichnykh zmin $\mathrm{v}$ yayechkakh neplidnykh cholovikiv zriloho viku, zumovlenykh alkoholizmom. Bulletin of Problems Biology and Medicine. 2019;4.1(153):221-3.

7. Erektylna dysfunktsiya. Pfizer Export B.V. Representative Office in Ukraine. 2018. Pfizer ID: PP-UGPUKR-0001. Available from: https://www.pfizermed.com.ua/ public/medical-content $/ \% \mathrm{D} 0 \% \mathrm{~B} 5 \% \mathrm{D} 1 \% 80 \% \mathrm{D} 0 \% \mathrm{~B} 5 \% \mathrm{D} 0$ $\% \mathrm{BA} \% \mathrm{D} 1 \% 82 \% \mathrm{D} 0 \% \mathrm{~B} 8 \% \mathrm{D} 0 \% \mathrm{BB} \% \mathrm{D} 1 \% 8 \mathrm{C} \% \mathrm{D} 0 \% \mathrm{BD} \%$ D0\%B0-\%D0\%B4\%D0\%B8\%D1\%81\%D1\%84\%D1\%83 $\% \mathrm{D} 0 \% \mathrm{BD} \% \mathrm{D} 0 \% \mathrm{BA} \% \mathrm{D} 1 \% 86 \% \mathrm{D} 1 \% 96 \% \mathrm{D} 1 \% 8 \mathrm{~F} / 2676$ [in Ukrainian].

8. Chaykovskyi YB, Polyvkan MI. Zminy hemodynamiky ta spermatohenezu u neoperovanykh cholovikiv v umovakh kosoyi pakhvynnoyi hryzhi. World of Medicine and Biology. 2017;1(59):87-9. [in Ukrainian].

9. Statistics "Zdorovya dlia vsikh" [cited 2020 Mar 3]. Available from: https://novadoba.kiev.ua/2020/03/03/5535

Received: 30.06 .2021

Revised: 23.11.2021

Accepted: 28.11.2021 